DOI https://doi.org/10.30525/978-9934-26-180-0-50

\title{
ВИКЛАДАННЯ ТЕМИ «НАВЧАННЯ МЕДІАЦЇ̈ ЯК ВИДУ ІНШОМОВНОГО СПІЛКУВАННЯ В ШКОЛІ» У ПЕДАГОГІЧНОМУ ЗАКЛАДІ ВИЩОЇ ОСВІТИ: ВИКЛИКИ І ПЕРСПЕКТИВИ
}

\author{
Долгушева О. В. \\ кандидат філологічних наук, \\ дочент кафедри германських мов та методик їхнього навчання \\ Центральноукраїнський державний педагогічний університет \\ імені Володимира Винниченка \\ м. Кропивницький, Украӥна
}

Медіація як вид комунікативної діяльності, яку відносно нещодавно було запроваджено у нормативних документах 3 мовної освіти європейської Спільноти (Common European Framework of Reference for Languages: Learning, Teaching, Assessment Companion Volume with New Descriptors від 2018 року), ще не набула достатнього висвітлення у вітчизняній методичній літературі та у навчальних програмах з методик навчання іноземних мов у закладах середньої освіти. Водночас, у педагогічних ЗВО спостерігається активне запровадження курсів з медіації, які, у переважній більшості випадків, обмежуються медіацією тексту. Тож актуальність статті обумовлена необхідністю вироблення конкретних рекомендацій навчання медіації у межах курсу методики викладання іноземної мови у закладах середньої освіти. Mета статmi - визначити труднощі, з якими стикаються студенти педагогічного ЗВО спеціальності «Середня освіта. Англійська мова і література» при теоретичному й практичному опануванні теми «Навчання медіації як комунікативної діяльності» та виробити рекомендації щодо їх усунення.

Навчання іноземних мов на сучасному етапі здійснюється у контексті діалогу культур. Відтак виникає потреба у формуванні в учителів іноземної мови і культури навичок та умінь тлумачення міжкультурних відмінностей. Це робить питання навчання медіації вкрай необхідним.

Медіацію зазвичай визначають як посередницьку мовленнєву діяльність, метою якої є забезпечення порозуміння між комунікантами, котрі не можуть спілкуватися безпосередньо. Роль медіатора, за таких умов, полягає у здійсненні допомоги у передачі смислу повідомлення від одного співрозмовника до іншого, підтримуючи інтерактивний характер взаємодії. Звісно, акцент робиться на ролі мови у створенні 
комунікативного простору та умов спілкування, навчання або співпраці 3 метою продукування й тлумачення значень, спонукання співрозмовників до обміну інформації однією чи різними мовами у різних сферах професійного чи особистого міжкультурного спілкування [1, с. 103].

На сучасний стан дослідження питання медіації як комунікативної діяльності вказує наявність таких публікацій вітчизняних дослідників: Д.С. Ципіної «Дидактичні засоби формування медіативної компетентності на занятті 3 іноземної мови» [10], О. Мольдерф «Медіація і професійна перекладацька діяльність в контексті оновлення загальноєвропейських рекомендацій з мовної освіти» [9], В.В. Волік «Медіація та iii місце у процесі навчання іноземної мови» [7], I. Єрастової-Михалусь та Д. Ципіної «Формування медіативної компетентності у процесі вивчення професійно-орієнтованої іноземної мови» [8] тощо.

Серед зарубіжних науковців питання медіації привернуло увагу Г. Сундарі «The features of mediation in EFL classroom interaction: Teacher perspectives» [6], I. Елге Жиджів'єне й В. Шлаужис «Teaching Mediation in EFL Classes at Secondary Schools in Lithuania and Poland: Challenges and Perspectives» [3], Г. Майр «Mediation and Task-Based Language Learning (TBLL): How Autonomous Learning Enhances Mediation Competencies» [5], П. Гоуелл "Cross-Language Mediation in Foreign Language Teaching» [4], Б. Дендрінос «Mediation in Communication, Language Teaching and Testing» [2].

Здебільшого наявні праці мають теоретичне спрямування i розглядають питання, пов'язаних із роллю медіації у процесі вивчення іноземної мови, зіставленням викладацького досвіду навчання медіації у різних країнах, опануванням медіації автономним здобувачем освіти, визначенням міжкультурної і міжмовної медіації, описом дескрипторів медіації за ЗСР, роллю медіації у підготовці фахівців з перекладу, розмежуванням понять перекладу й медіації, специфіки посередницької діяльності медіатора у залагодженні непорозумінь у конфліктних ситуаціях тощо.

Водночас кількість прикладних досліджень щодо медіації в царині методики навчання іноземних мов i культур вкрай обмежена. Це спричиняе у студентів педагогічних 3ВО труднощі опанування технологіями навчання учнів шкіл цього виду комунікативної діяльності. Власний досвід викладання цієї теми студентам Центральноукраїнського державного педагогічного університету спеціальності 014.021.Середня освіта. Мова i література (англійська) дозволяє узагальнити проблемні аспекти, які перешкоджають майбутніми учителям провадження 
успішного планування та здійснення медіаційних форм роботи під час уроку іноземної мови:

- студенти педагогічних спеціальностей зчаста ототожнюють переклад як вид медіації та переклад як засіб контролю розуміння учнями прочитаного чи прослуханого тексту або як спосіб семантизації лексичних одиниць;

- студенти не завжди усвідомлюють комплексний характер іншомовної комунікативної компетентності у медіації, яка інтегрує лінгвістичні компетенції, соціокультурну й комунікативну компетентності, нейтральність посередника тощо;

- під час укладання конспектів уроків студенти тяжіють до ототожнення методичних прийомів для формування медіаційної компетентності школярів із прийомами формування навичок й умінь монологічного i діалогічного іншомовного мовлення;

- студенти мають труднощі із створенням навчальних комунікативних ситуацій, у яких ключовими компонентами є чітко окреслений адресат, якому треба передати повідомлення, та поставленого завдання й мети, 3 якою таке повідомлення має бути продуковано й передано;

- студенти в обмеженому обсязі використовують додаткові автентичні матеріали для навчання медіації на уроках іноземної мови, мають труднощі із адаптуванням таких матеріалів до рівня володіння іншомовними мовленнєвими уміннями учнями різних вікових груп;

- створені студентами завдання на навчання здійснення мовного посередництва у переважній більшості обмежуються медіацією тексту (mediation of the text), натомість завдання стосовно медіації смислів (mediation of concepts) та комунікативної медіації (mediation of communication) у навчальних фрагментах уроків були відсутні;

- домінування неінтерактивних форм медіаційної діяльності, яку студенти планують організовувати й проводити під час уроку іноземної мови, унеможливлює усвідомлене здійснення функції підтримки процесу мовного посередництва як моделі справжнього міжкультурного спілкування.

3 метою усунення окреслених труднощів у методичній підготовці майбутніх вчителів іноземних мов і культур доцільним бачиться, поперше, розробити комплекс дидактичних матеріалів, орієнтованих на вправляння у посередницької діяльності у параметрах медіації смислів (mediation of concepts) та комунікативній медіації (mediation of communication); по-друге, на заняттях з фахових дисциплін (практики усного і писемного мовлення, країнознавства, лексикології, стилістики, літератури країни, мова якої вивчається, тощо) запровадити види роботи, 
які сприятимуть усвідомленню студентами якостей та умінь успішного медіатора (знання про рідну культуру й культуру носіїв мови, соціальні уміння й навички, що врегульовують правила поведінки, прийняті в кожній з культур, уміння й навички невербального спілкування, навички самоконтролю, емоційна стійкість тощо). По-третє, увести у навчальний план спецкурс з основ перекладу, під час вивчення якого студенти педагогічних спеціальностей удосконалюватимуть навички й уміння перекладу, у т.ч. як виду медіаційної діяльності; по-четверте, на заняттях 3 курсів медіації тексту передбачити професійно-орієнтовані завдання у роботі $з$ автентичними текстовими й медіаматеріалами (адаптування текстів до використання у навчальному процесі з учнями різних вікових груп, укладання лінгвістичного та екстралінгвістичного коментаря, що розрахований на школярів із різним рівнем володіння мовними, мовленнєвими і соціокультурними компетенціями та із урахування програмових вимог, роботу із комплексним опрацюванням вербальних й невербальних текстів тощо). Уміння й навички такої медіації тексту стануть у пригоді майбутнім вчителям іноземної мови під час безпосереднього здійснення професійної діяльності та розв'язанні низки дидактичних завдань.

\section{Література:}

1. Common European framework of reference for languages. Companion volume with new descriptors. Council of Europe, 2018. URL: https://rm.coe.int/cefr-companion-volumewith-new-descriptors-2018/ 1680787989

2. Dendrinos, B. Mediation in Communication, Language Teaching and Testing. URL: https://www.academia.edu/4711151/MEDIATION_IN_ COMMUNICATION_LANGUAGE_TEACHING_AND_TESTING

3. Žindžiuvienè, I.E., Szlaużys, W. Teaching Mediation in EFL Classes at Secondary Schools in Lithuania and Poland: Challenges and Perspectives. Lietuvos ir Lenkijos santykiu dinamika: nuo istorinès patirties iki šiuolaikinès situacijos: straipsniu rinkinys. Vilnius: Versus aureus, 2015. P. 51-75. https://vb.vdu.lt/object/elaba:8188262/

4. Howell, P. Cross-Language Mediation in Foreign Language Teaching. URL: https://ir.lib.hiroshima-u.ac.jp/files/public/4/42619/20170323145334480 810/h-gaikokugokenkyu_20_147.pdf

5. Mayr, G. Mediation and Task-Based Language Learning (TBLL): How Autonomous Learning Enhances Mediation Competencies. EL.LE, 2019. 8(3), P. 705-722. DOI 10.30687/ELLE/2280-6792/2019/03/010 
6. Sundari, $\mathrm{H}$. The features of mediation in EFL classroom interaction: Teacher perspectives. Indonesian EFL Journal, 2020. 6(1), P. 35-44. DOI: 10.25134/ieflj.v6i1.2636.

7. Волік В.В. Медіація та іiі місце у процесі навчання іноземної мови. Журнал науковий огляд. № 8(61), 2019. С. 91-104.

8. Єрастова-Михалусь І., Ципіна Д. Формування медіативної компетентності у процесі вивчення професійно-орієнтованої іноземної мови. Актуальні питання гуманітарних наук, 2020. Вип. 27, том 2, C. 206-210.

9. Мольдерф О. Медіація і професійна перекладацька діяльність в контексті оновлення загальноєвропейських рекомендацій з мовної освіти. Іноземна філологія, 2018. № 131. С. 71-80.

10. Ципіна Д. С. Дидактичні засоби формування медіативної компетентності на занятті з іноземної мови. Вісник Запорізького національного університету. Педагогічні науки, 2020. № 1 (34). C. 366-372.

DOI https://doi.org/10.30525/978-9934-26-180-0-51

\title{
THE PECULIARITIES OF TEACHING ENGLISH TO STUDENTS WITH DYSLEXIA
}

\author{
Zaika A. Yu. \\ Senior lecturer at the English Language Department \\ National University of Kyiv-Mohyla Academy \\ Kyiv, Ukraine
}

Learning foreign languages is an integral and obligatory part of the educational system of Ukraine. It is known that one of the most important types of communicative activity of students of higher educational institutions is reading, which is aimed at extracting information from a written fixed text. Reading provides students with a opportunities to develop their skills, including learning English. To learn to read correctly, it is necessary to understand what is being read correctly, to see what is written correctly and to correlate it correctly with what is pronounced. Disorder of the reading process, which makes it difficult to master this skill and leads to many mistakes during reading (omission of letters, syllables, their replacement and rearrangement, omission 